\title{
Interrelationships between biotin, choline and other B-vitamins and the occurrence of fatty liver and kidney syndrome and sudden death syndrome in broiler chickens
}

\author{
BY C. C. WHITEHEAD \\ Agricultural Research Council's Poultry Research Centre, Roslin, Midlothian EH25 9PS \\ AND C. J. RANDALL \\ Ministry of Agriculture, Fisheries and Food, Veterinary Laboratory, Lasswade, \\ Midlothian EHI8 $1 \mathrm{HU}$
}

(Received 15 December 1981-Accepted 12 March 1982)

\begin{abstract}
1. Addition of supplemental choline to a biotin-deficient diet decreased the biotin status of chicks and increased mortality from fatty liver and kidney syndrome (FLKS).

2. Mortality was also increased by dietary supplementation with a mixture of other B-vitamins, excluding biotin, and was highest when the choline and B-vitamin supplements were combined.

3. The occurrence of sudden death syndrome (SDS) was unaffected by dietary biotin concentration.

4. A previously unreported condition was observed in which birds died showing post-mortem signs characteristic of both FLKS and SDS and whose occurrence was related to the biotin status of the chicks.
\end{abstract}

Interactions between many vitamins have been reported which can influence the course of metabolic abnormalities and deficiency conditions. However, few instances of interrelationships between biotin and other B-vitamins have been reported. In an earlier experiment to demonstrate the involvement of vitamins in fatty liver and kidney syndrome (FLKS) Whitehead et al. (1976) found that, although biotin was specifically involved in preventing the syndrome, multivitamin supplements not containing biotin appeared to increase mortality. Mortality was especially high when the supplements contained choline and cyanocobalamin.

Since the extent of replication in that study was low, the effects of vitamins other than biotin on the occurrence of FLKS were reinvestigated. The first experiment confirmed the effect of choline and a second was therefore carried out to determine whether choline was affecting the biotin content of the diet or biotin metabolism in the bird.

In the course of the first experiment, a large number of birds died showing signs of both FLKS and sudden death syndrome (SDS). The aetiology of SDS, sometimes known as acute death syndrome (ADS) or flip-over disease, is unknown, but Hulan et al. (1980) have suggested that vitamins including biotin may be involved in its prevention. The condition has not been reported previously in conjunction with FLKS, hence a more detailed examination was made of birds dying in the second experiment. Results are also presented from two growth trials involving biotin, one of which was carried out in conjunction with Expt 1, in which mortality from FLKS or SDS or both was observed.

\section{MATERIALS AND METHODS}

\section{Husbandry}

The birds used were Ross broilers obtained as 1-d-old chicks from a commercial hatchery (Ross Poultry Ltd, Inverurie AB5 9JE). They were housed in floor pens $\left(3.72 \mathrm{~m}^{2}\right)$, forty-five birds/pen, containing a deep litter of white-wood shavings. They were reared under normal conditions of lighting ( $1 \mathrm{~h}$ darkness/d) and temperature and had free access to food and water at all times. 
Table 1. Compositions $(\mathrm{g} / \mathrm{kg})$ of basal diets

\begin{tabular}{lrr}
\hline & \multicolumn{2}{c}{ Diet } \\
\cline { 2 - 3 } \multicolumn{1}{c}{ Ingredient } & \multicolumn{1}{c}{2} \\
\hline Wheat & 644 & 750 \\
Soya-bean meal $(445 \mathrm{~g} \mathrm{CP} / \mathrm{kg})$ & 80 & - \\
Herring meal & 60 & 120 \\
Isolated soya-bean protein* & 50 & 60 \\
Maize starch & 125 & - \\
Vegetable oil & -30 \\
Limestone flour & 12 & 16 \\
Dicalcium phosphate & 18 & 15 \\
Salt & 2 & 2 \\
Methionine & 2 & 3 \\
Lysine & 2 & - \\
Vitamin and mineral supplement $\dagger$ & 5 & 5 \\
Measured analytical composition & & \\
CP & 185 & 227 \\
Diethyl ether extract & 18 & 54 \\
Total biotin $(\mu \mathrm{g} / \mathrm{kg})$ & 96 & 98 \\
\hline
\end{tabular}

$\mathrm{CP}$, crude protein (nitrogen $\times 6 \cdot 25$ ).

* FPD 950; Food Production Developments, 320 Kilburn Road, London.

$\uparrow$ Supplied (/kg diet) : retinol $20 \mathrm{mg}$, cholecalciferol $20 \mu \mathrm{g}$, $\alpha$-tocopherol $17 \mathrm{mg}$, menaphthone $1.3 \mathrm{mg}$, riboflavin $4 \mathrm{mg}$, nicotinic acid $28 \mathrm{mg}$, pantothenic acid $10 \mathrm{mg}$, copper $3.5 \mathrm{mg}$, iodide $0.4 \mathrm{mg}$, iron $80 \mathrm{mg}$, magnesium $300 \mathrm{mg}$, manganese $100 \mathrm{mg}$, zinc $50 \mathrm{mg}$.

\section{Diets}

The compositions of the basal diets are given in Table 1. Both diets were based on wheat to give them low available biotin contents but diet 1 had a lower protein level ( $180 \mathrm{~g}$ crude protein (nitrogen $\times 6.25) / \mathrm{kg}$ ) in order to induce a high level of mortality from FLKS (Blair et al. 1975) whereas diet 2 was thought to contain adequate amounts of all nutrients except biotin. Both diets contained similar amounts of total and available biotin. The experimental diets were obtained by supplementing the basal diets with additional vitamins in the amounts given in Tables 2 and 3. Choline was provided as the chloride absorbed on silica $(1: 1, w / w)$.

\section{Post-mortem examinations}

All birds that died in the experiments were examined post mortem. FLKS was diagnosed on the basis of the gross changes (Wight \& Siller, 1975) and SDS according to the description of Brigden \& Riddell (1975).

\section{Procedure}

Expt 1. The experiment was designed in two parts. The first investigated whether the adverse effect on FLKS mortality of a multivitamin supplement was attributable to choline or cyanocobalamin. The basal diet was diet 1 and four other diets were obtained by supplementing it with choline, cyanocobalamin, choline plus cyanocobalamin or these two vitamins plus thiamin, riboflavin, folic acid, nicotinic acid and pantothenic acid. Pyridoxine was omitted from the supplements because it was not implicated by the earlier results (Whitehead et al. 1976). Each diet was fed to four pens of females since these are usually more susceptible to FLKS (Whitehead et al. 1975).

The second part was an unrelated growth trial and involved feeding seven diets based on diet 2 supplemented with graded amounts of biotin, each to four pens of males.

Expt 2. This experiment was designed to reinvestigate the effects observed in Expt 1 . The 
basal diet was diet 1 and six other diets were obtained by adding biotin, choline or a multivitamin supplement containing thiamin, riboflavin, folic acid, nicotinic acid, pantothenic acid and cyanocobalamin as shown in Table 3. Each diet was fed to three pens of males and three of females.

At 3 weeks of age, blood pyruvate carboxylase (pyruvate:carbon-dioxide ligase (ADPforming), $E C$ 6.4.1.1; PC) activities were measured in twenty females from each of the diets supplemented with biotin, choline or biotin plus choline as well as from the basal diet. Enzyme activities with the other treatments were not measured for reasons of time. All birds were weighed at 4 weeks of age.

Expt 3. This was an experiment on biotin requirements for which growth results have been published (Whitehead \& Bannister, 1978). Four pens of males received each of the diets which were based on diet 2 and contained graded amounts of supplemental biotin.

\section{Biochemical methods}

Blood PC activity was measured by the method of Bannister \& Whitehead (1976).

Biotin contents of all diets were measured microbiologically by a method based on that of Wright \& Skeggs (1944).

Plasma glucose was measured by the method of Morley et al. (1968).

\section{Histological methods}

Blocks of liver, heart, kidney and lung were obtained post mortem from all birds in which SDS or combined SDS-FLKS were suspected. These were fixed in neutral buffered formalin and processed routinely for paraffin embedding. Sections were cut at $5 \mu \mathrm{m}$ and stained with haematoxylin and eosin (H \& E). Duplicate blocks of tissue were also fixed in formalin for the preparation of frozen sections, which were stained with Oil Red O.

\section{Diagnosis of disease states}

Diagnosis of FLKS. FLKS in Expt 1 was diagnosed on the basis of the characteristic gross appearance of birds. In Expt 2, histological examination of birds with this appearance confirmed that extensive fatty infiltration was present in liver, kidney and heart tissues. In some birds, fat droplets were also observed in epithelial cells lining the air capillaries and in the interstitium of the lung. Plasma glucose measurements from birds showing clinical signs typical of FLKS confirmed a severe hypoglycaemia:mean concentration was 3.7 $\mu \mathrm{mol} / \mathrm{ml}$ compared with $11.9 \mu \mathrm{mol} / \mathrm{ml}$ for healthy birds.

Diagnosis of SDS. Birds diagnosed as having died from SDS had a gross appearance very similar to that described by Brigden \& Riddell (1975) in that they had died in good bodily condition with digestive tracks full of food and showed a marked pulmonary congestion and oedema.

Diagnosis of FLKS combined with SDS. Birds diagnosed as having died from the combined effects of FLKS and SDS showed abnormalities characteristic of both syndromes at post-mortem examination. Livers and kidneys were pale and swollen and there was mild to severe bilateral congestion and oedema of lungs. Histological examination of frozen sections of tissues from twenty-one birds in Expt 2 confirmed that fatty infiltration was always present in liver and heart but sometimes the kidney was only mildly affected. Small amounts of fat were also seen in some lungs. $\mathrm{H} \&$ E-stained sections confirmed the presence of pulmonary congestion and oedema. Lipid droplets were occasionally observed in the oedematous fluid that was present in airways. Haemorrhage was present in the mucosa of the secondary bronchi in three broilers. 
Table 2. Expts 1 and 3. Mortality from fatty liver and kidney syndrome (FLKS) and sudden death syndrome (SDS) in male and female broilers given low-biotin diets containing additional supplements of vitamins

\begin{tabular}{|c|c|c|c|c|c|c|c|c|}
\hline \multirow[b]{2}{*}{$\begin{array}{l}\text { Expt } \\
\text { No. }\end{array}$} & \multirow[b]{2}{*}{$\begin{array}{c}\text { Basal } \\
\text { diet }\end{array}$} & \multirow[b]{2}{*}{$\begin{array}{l}\text { Additional supplemental } \\
\text { vitamins* }\end{array}$} & \multirow[b]{2}{*}{$\begin{array}{l}\text { No. of } \\
\text { birds }\end{array}$} & \multirow[b]{2}{*}{ Sex } & \multicolumn{4}{|c|}{ No. of deaths up to 8 weeks } \\
\hline & & & & & $\begin{array}{l}\text { FLKS } \\
\text { alone }\end{array}$ & $\begin{array}{l}\text { FLKS } \\
+ \text { SDS }\end{array}$ & $\begin{array}{l}\text { Total } \\
\text { FLKS }\end{array}$ & $\begin{array}{l}\text { SDS } \\
\text { alone }\end{array}$ \\
\hline \multirow[t]{12}{*}{1} & 1 & None & 180 & q & 39 & 3 & 42 & 1 \\
\hline & 1 & $\begin{array}{l}\text { Choline + cyanocobalamin } \\
+ \text { multivitamins }\end{array}$ & 180 & q & 41 & 28 & 69 & 0 \\
\hline & 1 & Choline & 180 & $q$ & 38 & 22 & 60 & 1 \\
\hline & 1 & Cyanocobalamin & 180 & $q$ & 36 & 2 & 38 & 0 \\
\hline & 1 & Choline + cyanocobalamin & 180 & 운 & 48 & 2 & 50 & 0 \\
\hline & 2 & Biotin $(\mu \mathrm{g} / \mathrm{kg}): \quad 70$ & 180 & $\delta$ & 3 & 1 & 4 & 1 \\
\hline & 2 & 100 & 180 & $\delta$ & 4 & 2 & 6 & 0 \\
\hline & 2 & 120 & 180 & $d$ & 3 & 3 & 6 & 1 \\
\hline & 2 & 140 & 180 & $\hat{\delta}$ & 2 & 0 & 2 & 0 \\
\hline & 2 & 160 & 180 & $\hat{d}$ & 2 & 0 & 2 & 1 \\
\hline & 2 & 180 & 180 & $\delta$ & 3 & 0 & 3 & 1 \\
\hline & 2 & 300 & 180 & $\delta$ & 1 & 0 & 1 & 2 \\
\hline \multirow[t]{7}{*}{3} & 2 & None & 180 & $\hat{d}$ & 5 & 0 & 5 & 1 \\
\hline & 2 & Biotin $(\mu \mathrm{g} / \mathrm{kg})$ : & 180 & $\delta$ & 4 & 0 & 4 & 0 \\
\hline & 2 & -6her of & 180 & $\hat{\sigma}$ & 1 & 0 & 1 & 0 \\
\hline & 2 & 100 & 180 & 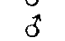 & 1 & 0 & 1 & 1 \\
\hline & 2 & 130 & 180 & 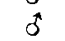 & 1 & 0 & $i$ & 1 \\
\hline & 2 & 200 & 180 & 8 & 1 & 0 & 1 & 1 \\
\hline & 2 & 500 & 180 & $\hat{\delta}$ & 0 & 0 & 0 & 0 \\
\hline
\end{tabular}

* Supplied (/ $\mathrm{kg}$ diet) : choline $3.1 \mathrm{~g}$, cyanocobalamin $0.14 \mathrm{mg}$ and, by multivitamin supplement, thiamin $3.5 \mathrm{mg}$, riboflavin $4 \mathrm{mg}$, folic acid $2 \cdot 1 \mathrm{mg}$, pantothenic acid $10 \mathrm{mg}$, nicotinic acid $28 \mathrm{mg}$.

\section{RESULTS}

Expt 1. The results of this experiment are summarized in Table 2. Mortality from FLKS (whether or not accompanied by SDS) was high on all diets not supplemented with biotin. Addition of cyanocobalamin to basal diet 1 had no effect on mortality but $\chi^{2}$ analysis showed that the addition of choline significantly $(P<0.05)$ increased mortality. Mortality was elevated further, though not significantly, by combination of the choline and multivitamin supplements. Where biotin was added, the occurrence of FLKS decreased in inverse relation to the supplemental amount.

Eight cases of uncomplicated SDS occurred, but these were not related to dietary biotin content. In contrast, sixty-three cases of SDS occurred in conjunction with FLKS, fifty of which were on the diets supplemented with choline or choline plus all the other supplemental vitamins.

Expt 2. Results from this experiment are given in Table 3. Analyses showed that the total biotin contents of the low-biotin diets were very similar and that the appropriate amounts of additional biotin had been added. The diets containing supplemental biotin resulted in significantly $(P<0.01)$ higher live weight at 4 weeks than with the basal diet whereas addition of choline or multivitamins or both significantly $(P<0.05)$ depressed live weight. Blood PC activity was significantly $(P<0.05)$ depressed when choline was added to the basal diet but was unaffected when it was added to the biotin-supplemented diet.

Mortality from FLKS was twice as high in females as in males. $\chi^{2}$ analysis showed it was increased significantly $(P<0.001)$ by the addition of choline. Addition of the 
Table 3. Expt 2. Live weight, blood pyruvate carboxylase (pyruvate : carbon dioxide ligase (ADPforming), EC 6.4.1.1; PC) activity and mortality from fatty liver and kidney syndrome $(F L K S)$ or sudden death syndrome (SDS) or both in male and female broilers given basal diet 1 supplemented with additional vitamins

(Blood PC activities, expressed as $\mathrm{nmol}^{14} \mathrm{CO}_{2}$ incorporated/g haemoglobin per min at $38^{\circ}$, are means with their standard errors of measurements on twenty females)

\begin{tabular}{|c|c|c|c|c|c|c|c|c|c|c|}
\hline \multirow{2}{*}{$\begin{array}{c}\text { Additional } \\
\text { supplemental } \\
\text { dietary vitamins* }\end{array}$} & \multirow{2}{*}{$\begin{array}{l}\text { Dietary } \\
\text { biotin } \\
\text { content } \\
(\mu \mathrm{g} / \mathrm{kg})\end{array}$} & \multirow[b]{2}{*}{ Sex } & \multirow[b]{2}{*}{$\begin{array}{c}\text { No. of } \\
\text { birds }\end{array}$} & \multirow{2}{*}{$\begin{array}{c}\text { Mean } \\
\text { live wt } \\
\text { at } 4 \text { weeks } \\
\text { (g) }\end{array}$} & \multirow{2}{*}{$\begin{array}{l}\text { Blood PC } \\
\text { activity } \\
\text { at } 3 \text { weeks }\end{array}$} & & \multicolumn{4}{|c|}{ No. of deaths up to 7 weeks } \\
\hline & & & & & & & $\begin{array}{l}\text { FLKS } \\
\text { alone }\end{array}$ & $\frac{\text { FLKS }}{\text { SDS }}$ & $\begin{array}{l}\text { Total } \\
\text { FLKS }\end{array}$ & $\begin{array}{l}\text { SDS } \\
\text { alone }\end{array}$ \\
\hline None & 96 & 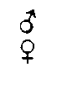 & $\begin{array}{l}135 \\
135\end{array}$ & $\begin{array}{c}691 \\
632 \\
\text { Mean } 662^{\text {ac }}\end{array}$ & $77^{\mathrm{a}}$ & Total & $\begin{array}{r}2 \\
8 \\
10\end{array}$ & $\begin{array}{l}1 \\
4 \\
5\end{array}$ & $\begin{array}{r}3 \\
12 \\
15\end{array}$ & $\begin{array}{l}1 \\
0 \\
1\end{array}$ \\
\hline Choline & 93 & $\begin{array}{l}0 \\
\text { ô }\end{array}$ & $\begin{array}{l}135 \\
135\end{array}$ & $\begin{array}{r}672 \\
585 \\
\text { Mean } 629^{\circ}\end{array}$ & $55^{\mathrm{b}}$ & Total & $\begin{array}{l}10 \\
21 \\
31\end{array}$ & $\begin{array}{l}2 \\
2 \\
4\end{array}$ & $\begin{array}{l}12 \\
23 \\
35\end{array}$ & $\begin{array}{l}0 \\
0 \\
0\end{array}$ \\
\hline Multivitamins & 91 & $\begin{array}{l}0 \\
q\end{array}$ & $\begin{array}{l}135 \\
135\end{array}$ & $\begin{array}{c}661 \\
614 \\
\text { Mean } 638^{\text {bc }}\end{array}$ & - & Total & $\begin{array}{r}6 \\
13 \\
19\end{array}$ & $\begin{array}{l}1 \\
3 \\
4\end{array}$ & $\begin{array}{r}7 \\
16 \\
23\end{array}$ & $\begin{array}{l}0 \\
0 \\
0\end{array}$ \\
\hline $\begin{array}{l}\text { Choline + multj- } \\
\text { vitamins }\end{array}$ & 94 & $\begin{array}{l}0 \\
0 \\
+\end{array}$ & $\begin{array}{l}135 \\
135\end{array}$ & $\begin{array}{r}654 \\
595 \\
\text { Mean } 625^{b}\end{array}$ & - & Total & $\begin{array}{l}12 \\
28 \\
40\end{array}$ & $\begin{array}{r}5 \\
7 \\
12\end{array}$ & $\begin{array}{l}17 \\
35 \\
52\end{array}$ & $\begin{array}{l}0 \\
1 \\
1\end{array}$ \\
\hline Biotin & 173 & $\begin{array}{l}0 \\
0 \\
+\end{array}$ & $\begin{array}{l}135 \\
135\end{array}$ & $\begin{array}{r}740 \\
677 \\
\text { Mean } 708^{d}\end{array}$ & $\overline{97^{\mathrm{c}}}$ & Total & $\begin{array}{l}3 \\
0 \\
3\end{array}$ & $\begin{array}{l}0 \\
0 \\
0\end{array}$ & $\begin{array}{l}3 \\
0 \\
3\end{array}$ & $\begin{array}{l}0 \\
0 \\
0\end{array}$ \\
\hline Biotin + choline & 181 & $\begin{array}{l}\delta \\
q\end{array}$ & $\begin{array}{l}135 \\
135\end{array}$ & $\begin{aligned} 746 \\
699 \\
\text { Mean } 723^{d}\end{aligned}$ & $98^{\mathrm{c}}$ & Total & $\begin{array}{l}0 \\
0 \\
0\end{array}$ & $\begin{array}{l}3 \\
2 \\
5\end{array}$ & $\begin{array}{l}3 \\
2 \\
5\end{array}$ & $\begin{array}{l}0 \\
0 \\
0\end{array}$ \\
\hline $\begin{array}{l}\text { Biotin }+ \text { choline }+ \\
\text { multivitamins }\end{array}$ & 194 & $\begin{array}{l}0 \\
0 \\
q\end{array}$ & $\begin{array}{l}135 \\
135\end{array}$ & $\begin{array}{r}726 \\
701 \\
\text { Mean } 714^{d}\end{array}$ & - & Total & $\begin{array}{l}0 \\
0 \\
0\end{array}$ & $\begin{array}{l}2 \\
0 \\
2\end{array}$ & $\begin{array}{l}2 \\
0 \\
2\end{array}$ & $\begin{array}{l}0 \\
0 \\
0\end{array}$ \\
\hline $\begin{array}{l}\text { Pool standard } \\
\text { error of mean }\end{array}$ & & & & $10 \cdot 2$ & $6 \cdot 6$ & & & & & \\
\hline
\end{tabular}

* Supplemental biotin concentration was $100 \mu \mathrm{g} / \mathrm{kg}$. For concentrations of other vitamins see Table 2 .

$\mathrm{a}, \mathrm{b}, \mathrm{c}, \mathrm{d}$, Values in the same vertical column that do not share a common superscript letter were significantly' tifferent $(P<0.05)$.

multivitamin mixture to either the basal or choline-supplemented diet increased mortality significantly $(P<0.05)$. A low incidence of FLKS occurred with the biotin-supplemented diets but an adverse effect of other supplemental vitamins was not apparent.

Eight birds that died were thought, on macroscopic appearance, to be uncomplicated cases of SDS. In only two of these, however, was fat absent in the frozen tissue sections; the remaining six had variable deposits of fine lipid droplets in the liver, heart, kidneys and lungs and were thus classified as having the combined condition. There was a high incidence of the latter in this experiment. It appeared equally in both sexes and, although its occurrence in relation to FLKS alone was variable, the highest incidence occurred with the diet also causing most FLKS.

Expt 3. The incidence of FLKS was low in this experiment (Table 2) but the distribution appeared to be related to the biotin content of the diet. SDS was not observed in association with FLKS, but the four cases of typical SDS occurred on diets of widely differing biotin content. 


\section{DISCUSSION}

Mortality from FLKS was much lower with diets based on basal diet 2, as a result the higher protein and fat contents of this diet (Blair et al. 1975). The smaller differences in mortality with the same basal diet in different experiments were probably due to changes in the many nutritional and environmental factors known to influence the occurrence of the syndrome. However the results confirm previous observations (Whitehead et al. 1976) that the addition of extra quantities of B-vitamins to biotin-deficient diets has an adverse effect on biotin metabolism and the incidence of FLKS. The results from Expt 1 indicated that choline alone, though not cyanocobalamin, can increase mortality and also suggested that a mixture of other B-vitamins could enhance this effect when provided in conjunction with choline. These conclusions were supported by results from the more detailed investigation undertaken in Expt 2 where both choline and a multivitamin supplement separately increased mortality. Moreover, their effect was additive since mortality was significantly increased when choline was combined with the multivitamin supplement.

These conclusions were supported by other criteria of biotin status. The biotin-deficient nature of basal diet 1 was confirmed by dietary biotin analysis and by the growth response in Expt 2 when supplemental biotin was added. However, addition of choline or a multivitamin supplement or both to the basal diet depressed growth of both sexes. Metabolic measurements also confirmed the adverse effect of additional choline in the basal diet since blood PC activity, shown by Whitehead \& Bannister (1980) to be a good criterion of biotin status and requirement in broilers, was depressed significantly below the activity found in birds given the basal diet.

The interaction between biotin and the other vitamins takes place in the birds rather than in the diets since the biotin contents of the diets, measured at the time they were fed, were unaffected by the presence of other vitamins. Thus biotin was not destroyed by choline which is a potentially caustic substance and is known to destabilize other vitamins, especially in the presence of moisture (Kläui, 1975). The interaction between the vitamins in the bird appeared to enhance the severity of the existing biotin deficiency rather than the absolute requirement. Thus growth rate and blood PC activity were decreased and FLKS mortality was increased by supplementation of the low biotin diet but these aspects were unaffected by the presence of other vitamins in the biotin-supplemented diets. Other instances of one vitamin enhancing the deficiency of another are known: in pigs, Cunha $e t$ al. (1948) found that the severity of biotin deficiency was increased by the provision of extra folic acid and cyanocobalamin. Interactions between the latter two vitamins and choline in methyl group metabolism are well documented but the relationship between biotin and choline or methyl group metabolism is obscure. However, the present results serve as a reminder that B-vitamin supplementation of poultry diets should be aimed at ensuring an adequate metabolic balance in the birds.

The diagnostic basis for SDS is limited. However, the experimental cases closely resembled those submitted to the Veterinary Laboratory from local farms. Uncomplicated SDS occurred in all the experiments reported, although the incidences were rather low to allow firm conclusions to be drawn about nutritional involvement. However, no dietary trends were apparent. Mortality was not higher with the diets lacking supplemental biotin and, where graded levels of supplemental biotin were provided, there was no dose-response relationship. The provision of extra choline or other B-vitamins did not prevent the syndrome. There was thus no evidence that B-vitamins are directly involved in SDS. This conclusion is at variance with observations by Hulan et al. (1980) that biotin and other vitamins reduced mortality from SDS, although these authors did not find a relationship between mortality and the dietary level of any individual or mixture of vitamins. 
The combination of the signs of FLKS and SDS has not been reported previously, nor was it observed in earlier experiments at the Poultry Research Centre even when high incidences of FLKS were induced repeatedly (Whitehead \& Blair, 1976). However, cases with the combined abnormalities have been submitted recently to the Veterinary Laboratory from local farms.

Histological examination confirmed that changes typical of FLKS, such as fatty infiltration of liver, kidney and heart, were present although the extent of infiltration was usually not so severe as when signs of SDS were absent. Fatty infiltration in lung has not been reported previously in FLKS but was observed in some birds affected with either combined FLKS and SDS or FLKS alone. The abnormalities of SDS were similar to those seen in the uncomplicated condition, i.e. congestion and oedema of lungs and heart abnormalities although the congestion was often milder than in uncomplicated SDS. It is not possible at this stage to be certain that these abnormalities are attributable to SDS since the manner of death was not observed and the diagnosis of SDS is based on so few criteria. There is even doubt as to whether lung congestion and oedema occur at the time of death or post mortem (Riddell \& Orr, 1980). Nevertheless we think that the abnormalities seen are consistent with the combined occurrence of the two syndromes.

The occurrence of the combined syndrome was very variable but in general was related to the biotin content of the diet, as was FLKS. In view of the lack of association between SDS and biotin, it is likely that the combined condition is related more directly to FLKS than to biotin. The aetiology of FLKS is well understood and involves a failure of hepatic gluconeogenesis via pyruvate carboxylase caused by a lack of biotin. When the bird is stressed or fasted, limited reserves of glycogen are consumed and a hypoglycaemia develops which results in morbidity and death in a few hours. In response to the hypoglycaemia, fatty infiltration of tissues is thought to occur (for a review of the biochemical effects of FLKS, see Bannister, 1979). In view of the sudden nature of SDS, it is likely that in the combined condition the birds are affected initially with FLKS and subsequently develop SDS. The death of these birds before the full progression of FLKS occurred could explain why the post-mortem signs of FLKS were sometimes less severe than in birds dying from FLKS alone. Similarly, the presence of FLKS may have affected the post-mortem appearance of SDS, which was less striking than in birds that were diagnosed as having died from SDS alone. The apparent association between the two conditions suggests that an abnormality occurring as a result of FLKS may contribute to the initiation of SDS. If there is thus a causal relationship between FLKS and SDS, it follows that biotin, though not directly implicated in SDS, may nevertheless decrease the apparent incidence of sudden death by preventing FLKS.

The authors thank Mr R. Morley Jones for statistical analyses of data, Mrs I. E. O'Neill for measurements of plasma glucose concentrations, $\mathrm{Mr}$ J.A. Armstrong and $\mathrm{Mrs}$ C. E. McNeill for measurements of enzyme activities and F. Hoffmann-La Roche \& Co., for dietary biotin assays. Excellent technical assistance was provided by members of the Pathology section at Lasswade.

\section{REFERENCES}

Bannister, D. W. (1979). Int. J. Biochem. 10, 193.

Bannister, D. W. \& Whitehead, C. C. (1976). Int. J. Biochem. 7, 619.

Blair, R., Whitehead, C. C. \& Teague, P. W. (1975). Res. vet. Sci. 18, 76.

Brigden, J. L. \& Riddell, C. (1975). Can. vet. J. 16, 194.

Cunha, T. J., Colby, R. W., Busted, L. K. \& Bone, J. F. (1948). J. Nutr. 36, 215.

Hulan, H. W., Proudfoot, F. G. \& McRae, K. B. (1980). Poult. Sci. 59, 927.

Kläui, H. (1975). Stability and losses of vitamins during mixing, pelleting and conservation of feeds. Basle: Roche Information Service. 
Morley, G., Dawson, A. \& Marks, V. (1968). Proc. soc. clin. Biochem. 5, 42.

Riddell, C. \& Orr, J. P. (1980). Avian Dis. 24, 751.

Whitehead, C. C. \& Bannister, D. W. (1978). Proc. XVI Wld's Poult. Congr., Rio de Janeiro, p. 1927.

Whitehead, C. C. \& Bannister, D. W. (1980). Br. J. Nutr. 43, 541.

Whitehead, C. C. \& Blair, R. (1976). Res. vet. Sci. 21, 141.

Whitehead, C. C. Blair, R., Bannister, D. W. \& Evans, A. J. (1975). Res. vet. Sci. 18, 100.

Whitehead, C. C., Blair, R. Bannister, D. W., Evans, A. J. \& Jones, R. M. (1976). Res. vet. Sci. $20,180$.

Wight, P. A. L. \& Siller, W. G. (1975). Res. vet. Sci. 19, 173.

Wright, L. D. \& Skeggs, H. R. (1944). Proc. Soc. exp. Biol. Med. 56, 95. 